\title{
PHYSICAL QUALITY OF AN OXISOL AFTER DIFFERENT PERIODS OF MANAGEMENT SYSTEMS ${ }^{(1)}$
}

\author{
Karina de Vares Rossetti ${ }^{(2)}$, José Frederico Centurion ${ }^{(3)}$ \& Eurico Lucas de Sousa Neto ${ }^{(4)}$
}

\begin{abstract}
SUMMARY
Management systems may lead to a loss of soil physical quality as a result of removal of the plant cover and excessive agricultural mechanization. The hypothesis of this study was that the soil aggregate stability, bulk density, macro- and microporosity, and the $S$ index and saturated hydraulic conductivity may be used as indicators of the soil physical quality. The aim was to study the effects of different periods and managements on the physical attributes of a medium-textured Red Oxisol under soybean and corn for two growing seasons, and determine which layers are most susceptible to variations. A completely randomized experimental design was used with split plots (five treatments and four layers), with four replications. The treatments in 2008/09 consisted of: five years of no-tillage (NTS5), seven years of no-tillage (NTS7), nine years of no-tillage (NTS9), conventional tillage (CTS) and an adjacent area of native forest (NF). The treatments were extended for another year, identified in 2009/10 as: NTS6, NTS8, NTS10, CTS and NF. The soil layers 0-0.05, 0.05-0.10, 0.10-0.20 and 0.20-0.30 $\mathrm{m}$ were sampled. The highest $\mathrm{S}$ index values were observed in the treatment CTS in the 0-0.05 $\mathrm{m}$ layer (0.106) and the $0.05-0.10 \mathrm{~m}$ layer $(0.099)$ in $2008 / 09$, and in the $0-0.05 \mathrm{~m}$ layer $(0.066)$ in $2009 / 10$. This fact may be associated with soil turnover, resulting in high macroporosity in this treatment. In contrast, in the NTS, limiting macroporosity values were observed in some layers (below $0.10 \mathrm{~m}^{3} \mathrm{~m}^{-3}$ ). Highest aggregate stability as well as the highest saturated hydraulic conductivity $(\mathrm{K} \theta)$ values were observed in NF in relation to the other treatments. In 2009/10, the K $\theta$ in NF differed only from NTS10. This study showed that the use of the $\mathrm{S}$ index alone cannot be recommended as an absolute indicator of the soil physical quality, even at values greater than 0.035 .

Index terms: aggregation, $\mathrm{S}$ index, saturated hydraulic conductivity.
\end{abstract}

(1) Part of the Master Dissertation of the first author, funded by FAPESP ( $\mathrm{n}^{\circ}$ 2008/52793-6), and presented to the Soil Science Program of the Faculdade de Ciências Agrárias e Veterinárias - FCAV/UNESP. Received for publication on October 3,2012 and approved on August 22, 2013.

(2) Doctoral student in Agronomy, Vegetal Production, FCAV/UNESP. Prof. Donato Castellane, s/n. CEP $14884-900$ Jaboticabal (SP), Brazil. CAPES fellowship. E-mail: krossetti@bol.com.br

(3) Adjunct Professor, Soil and Fertilization Department, FCAV/UNESP. CNPq fellowship. E-mail: jfcentur@fcav.unesp.br

(4) Professor, Mato Grosso State University - UNEMAT. Department of Animal Production. P.O. Box 181. CEP 78250-000 Pontes e Lacerda (MT), Brazil. E-mail: euriconeto@unemat.br 


\title{
RESUMO: QUALIDADE FÍSICA DE UM LATOSSOLO SOB DIFERENTES TEMPOS E MANEJOS
}

\begin{abstract}
Os sistemas de manejo podem ocasionar a perda da qualidade do solo, em decorrência da retirada da cobertura vegetal e do excessivo uso da mecanização. A hipótese desta pesquisa foi que a estabilidade de agregados, a densidade do solo, a macro e a microporosidade do solo, o índice $S$ e a condutividade hidraúlica saturada pudessem ser utilizados como indicadores de qualidade física do solo. Diante disso, objetivaram-se estudar os efeitos dos diferentes tempos e manejos nos atributos físicos de um Latossolo Vermelho de textura média, cultivado por dois anos agrícolas, com soja e milho e determinar quais são as camadas mais susceptíveis a variações. O delineamento experimental foi inteiramente casualizado com parcelas subdivididas (cinco tratamentos e quatro camadas), com quatro repetições. Os tratamentos em 2008/09 foram: plantio direto por cinco anos (NTS5), plantio direto por sete anos (NTS7), plantio direto por nove anos (NTS9), preparo convencional (CTS) e área adjacente de mata nativa (NF). Os tratamentos estenderam-se para o ano de 2009/10, assim identificados: NTS6, NTS8, NTS10, CTS e NF; as camadas de solo estudadas foram: 0-0,05; 0,05-0,10; 0,10-0,20; e 0,20-0,30 m. Os maiores valores do indice $S$ foram observados no CTS nas camadas de 00,05 (0,106) e 0,05-0,10 m (0,099), no ano de 2008/09; e na de 0-0,05 m (0,066), em 2009/10. Esse fato pode estar associado ao revolvimento, resultando em elevadas macroporosidades do solo neste tratamento. Em contraposição, no NTS, verificou-se ocorrência de valores restritivos de macroporosidade em algumas camadas (abaixo de $0,10 \mathrm{~m}^{3} \mathrm{~m}^{-3}$ ). Constatou-se que a maior estabilidade de agregados assim como os maiores valores de condutividade hidraúlica saturada

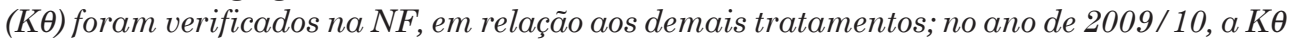
na NF somente diferiu do NTS10. Pode-se afirmar com este estudo que apenas o uso do indice $S$ não é recomendável como indicador absoluto de qualidade física do solo, mesmo tendo apresentado valores superiores a 0,035.
\end{abstract}

Termos de indexação: agregação, índice S, condutividade hidraúlica saturada.

\section{INTRODUCTION}

The time periods after the adoption of management practices promote diverse alterations in soil physical attributes, as in pore distribution, soil bulk density and aggregation, which affect the capacity for water retention and infiltration (Loss et al., 2009). The modifications in these physical attributes are more pronounced when a transition from natural environments to agricultural systems takes place, or appear during the implementation of conservation systems in substitution of conventional soil tillage systems.

It is known that the conventional tillage system, compared to the no-tillage system, reduces the aggregate stability and accelerates organic matter decomposition; however, it increases the pore volume, permeability and air flow, facilitating plant root growth in the tilled layer. Usually, these characteristics are lost when the bare soil is exposed to natural rainfall. This effect leads to disaggregation and to scattering of the soil particles through the direct impact of raindrops, which contributes to a decrease in water infiltration and surface runoff (Volk et al., 2004).

The adoption of conservation systems, e.g., notillage, includes the maintenance of crop residues on the soil surface, which is an influential factor for improvements in the soil structure. These improvements are reflected in water infiltration, reduction in soil surface temperature and an increase in soil aggregate stability. However, even in the notillage system, the water infiltration capacity of the soil can decrease, due to particle densification and greater soil bulk density in the surface layers (Pinheiro et al., 2009).

In this respect, the impacts of management practices on soil physical quality have been quantified using physical properties related to structural shape and stability, such as aggregate stability, bulk density and soil porosity (Aratani et al., 2009). The S index, introduced in Brazil based on the work of Dexter (2004), is calculated from the water retention curve (WRC). It is a parameter that assesses the structural porosity, i.e., the microcracks, cracks, biopores and macrostructural pores resulting from land use and management; a greater $\mathrm{S}$ value represents a greater slope of the WRC, indicating better pore distribution and greater quantity of larger-diameter pores.

According to Dexter (2004), based on information regarding critical values of organic matter in soils in Poland and England, it was established that the boundary between soils of good and poor structural quality occurs at an $\mathrm{S}$ value of around 0.035 . However, this value is not applicable to tropical soils. Thus, Andrade \& Stone (2009) carried out a study of the S index for soils of the cerrado (Brazilian tropical savanna) in the central west and northeast regions of Brazil, and verified that a boundary value of $S=0.045$ proved adequate for the division between soil with good 
structural quality and soil tending to degradation, while $\mathrm{S} \leq 0.025$ indicates physically completely degraded soils. Nevertheless, according to Jong van Lier (2012), the analysis with the S index as an indicator of soil physical quality must be interpreted with caution since this index includes no threshold values that are independent of soil type and environment. According to this author, the use of the $\mathrm{S}$ index can be recommended for comparing a soil under different uses or agricultural managements within a single soil system. In addition, the development of a systematic analysis or of an index of the physical properties that may be possible indicators of the soil physical quality is also indispensable. The hypothesis of this study is that the soil aggregate stability, bulk density, macro- and microporosity, and the $\mathrm{S}$ index and saturated water conductivity may be used as indicators of the soil physical quality. The aim of this study was to evaluate the effects of different managements and time periods since their adoption on the physical attributes of a Red Oxisol cultivated for two years with soybean and corn, and determine which soil layers are most susceptible to variations.

\section{MATERIALS AND METHODS}

The experiment was conducted in Jaboticabal, São Paulo State, Brazil (21 $1^{\circ} 14^{\prime} 05^{\prime \prime}$ latitude South, $48^{\circ} 17^{\prime} 09^{\prime \prime}$ longitude West; average altitude of 615.01 $\mathrm{m}$ asl). The climate in the region, according to the Köppen classification, is Cwa, with hot summers and dry winters, an average annual rainfall of $1,428 \mathrm{~mm}$ and average temperature of $21^{\circ} \mathrm{C}$. The soil used was a typic dystrophic Red Oxisol, medium texture, moderate A horizon, koalinitic, hypoferric, very deep and with flat to slightly undulating relief (Embrapa, 2006), with $330 \mathrm{~g} \mathrm{~kg}^{-1}$ clay, $40 \mathrm{~g} \mathrm{~kg}^{-1}$ silt and $630 \mathrm{~g} \mathrm{~kg}^{-1}$ sand in the 0-0.30 m layer (Embrapa, 2011).

Before setting up the experiment, the soil had been under a conventional tillage system for 30 years, with annual succession of corn and soybean in the summer and a second corn crop in the fall. No-tillage systems were implemented in the years 2000, 2002 and 2004, resulting in the treatments: a nine-year no-tillage system (NTS9), a seven-year no-tillage system (NTS7), and a five-year no-tillage system (NTS5) in the 2008/09 growing season. In the following year, treatments consisted of: a 10-year no-tillage system (NTS10), an eight-year no-tillage system (NTS8), and a six-year no-tillage system (NTS6) in the 2009/10 growing season. In the 2008/09 growing season, four $60 \mathrm{~m}^{2}$ plots were dedicated to conventional tillage (CTS); the other areas of the management systems were also $60 \mathrm{~m}^{2}$ plots. The CTS consisted of chisel plowing to a depth of $0.30 \mathrm{~m}$, followed by heavy disking and light disking.

In November 2008, the soybean cultivar M-SOY 6101 was sown (depth $0.03 \mathrm{~m}$, inter-row spacing
$0.45 \mathrm{~m})$. Chemical analysis of the soil was carried out according to Raij et al. (2001) and fertilization consisted of the application of $250 \mathrm{~kg} \mathrm{ha}^{-1}$ of the N-P-K fertilizer 2-20-20 $\left(\mathrm{N}-\mathrm{P}_{2} \mathrm{O}_{5}-\mathrm{K}_{2} \mathrm{O}\right)$ in the plots at sowing. Corn (hybrid Impacto; Syngenta $^{\odot}$ ) was sown (depth $0.03 \mathrm{~m}$, inter-row spacing $0.90 \mathrm{~m}$ ), in December 2009. Fertilization consisted of the application of $300 \mathrm{~kg} \mathrm{ha}^{-1}$ of the N-P-K fertilizer 8-20-20 (N- $\left.\mathrm{P}_{2} \mathrm{O}_{5}-\mathrm{K}_{2} \mathrm{O}\right)$ in the plots at sowing. In the crop stage V6, topdressing fertilization was carried out, consisting of $0.250 \mathrm{Mg} \mathrm{ha}^{-1}$ of the N-P-K fertilizer 20-0-10 $\left(\mathrm{N}-\mathrm{P}_{2} \mathrm{O}_{5}-\mathrm{K}_{2} \mathrm{O}\right)$ applied at the soil surface along the planting line.

In the 2008/09 growing season, the treatments NTS5, NTS7, NTS9, and CTS were tested, and an adjacent native forest area was used as control (NF). The treatments in the 2009/10 growing season were NTS6, NTS8, NTS10, CTS and NF. The experiments were conducted in a completely randomized design, in split-plots with four replications. The plots consisted of the treatments, and the split-plots of the sampled soil layers (0-0.05, 0.05-0.10, 0.10-0.20 and 0.20-0.30 m).

During the flowering of the crops, undisturbed soil samples were collected at four random points in each treatment between the crop rows with a $53.1810^{-6} \mathrm{~m}^{3}$ cylindrical sampler (height $0.032 \mathrm{~m}$, diameter $0.046 \mathrm{~m}$ ) to determine the soil physical properties. The samples were saturated for $24 \mathrm{~h}$ and subjected to different tensions $(10,30,60,100,330,600,1000$, and $3000 \mathrm{hPa}$ ) in a Richards pressure chambers. The following items were determined in these samples: water content retained at each tension (Klute, 1986); soil bulk density (BD), according to Blake \& Hartge (1986); microporosity by drying at a tension of $60 \mathrm{hPa}$ (pores $<50 \mu \mathrm{m}$ ); and total porosity according to Danielson \& Sutherland (1986). Macroporosity (pores $>50 \mu \mathrm{m}$ ) was calculated as the difference between total porosity and microporosity. Water retention curves were obtained by fitting the model proposed by van Genuchten (1980), from which the slope of the curve at the point of inflection was obtained and, consequently, the Sindex, as proposed by Dexter (2004).

For analysis of aggregates in water, the collected samples were air-dried, carefully broken up, and passed through $7.93 \mathrm{~mm}$ sieves. Specimens of $50 \mathrm{~g}$ were taken from the aggregates retained in the $4 \mathrm{~mm}$ sieve, which were pre-moistened according to the slow wetting principle described by Kemper \& Chepil (1965). The samples were then placed in a wet-sieving apparatus, on a set of sieves (mesh diameter 4.00, $2.00,1.00,0.50,0.25$ and $0.125 \mathrm{~mm}$ ), as described by Yoder (1936). After $15 \mathrm{~min}$, the particles retained in each sieve were transferred to aluminum cans with jets of water and dried in a laboratory oven at $105^{\circ} \mathrm{C}$ for $24 \mathrm{~h}$ for later weighing. Based on these weight values, the percentage of water-stable aggregates with diameter greater than $2.00 \mathrm{~mm}$ (Aggregation), the mean geometric diameter (MGD), and the weighted mean diameter of the aggregates (WMD) were calculated according to Kemper \& Chepil (1965). 
Samples were also removed from the different layers for chemical analysis for the determination of soil organic matter (OM), according to the method described by Raij et al. (2001).

The saturated hydraulic conductivity of the soil in the management systems was determined at four points per plot using the $2800 \mathrm{KI}$ Guelph Permeameter (at a depth $0.15 \mathrm{~m}$ ) and subjected to two hydraulic heads (0.03 and $0.06 \mathrm{~m}$ of water column). Readings were made by means of the water level of the column in the device and, from the moment of stabilization of the readings, the average of the last three readings was used and saturated hydraulic conductivity (K $\theta)$ was calculated according to the equation:

$\mathrm{K} \theta=\{[(0.0041) *(32.29) *(\mathrm{x} 1)]\}-\{[(0.0054) *(35.39) *$ $(\mathrm{x} 2)]\} * \mathrm{fc}$

in which $\mathrm{x} 1$ represented the average of the last three measurements (hydraulic head of the water column of $0.06 \mathrm{~m}$ ) in $\mathrm{cm} \mathrm{s}^{-1} ; \mathrm{x} 2$, the average of the last three readings (hydraulic head of the water column of 0.03 $\mathrm{m}$ ), in $\mathrm{cm} \mathrm{s}^{-1}$; and fc, the conversion factor for $\mathrm{mm} \mathrm{h}^{-1}$.

The results were subjected to analysis of variance in a completely randomized design and in split-plots; and the treatments were evaluated separately in each growing season. The software ASSISTAT version 7.5 beta was used for this purpose; when significant, the mean values were compared by the Tukey test $(p<0.05)$ (Banzatto \& Kronka, 1992).

\section{RESULTS AND DISCUSSION}

The aggregate stability determined by means of the weighted mean diameter (WMD) (Table 1) in the treatment with the longest use of no-tillage, NTS9, in 2008/09 (4.88 $\mathrm{mm}$ ) and NTS10 in 2009/10 (4.63 mm) in the 0-0.05 m layer was not sufficient to promote the formation of larger aggregates, unlike in the soil under NF. It noteworthy that the greater the WMD index, the higher is the proportion of the major aggregate class, whereas the mean geometric diameter (MGD) represents only an estimate of the classes of greatest occurrence. In contrast, Assis \& Lanças (2010) stated that the distribution of soil aggregates in a notillage system (12 years) was closest to that of soil under native forest. Soil aggregation under conventional tillage was in some cases similar to notillage in all layers evaluated in 2008/09, contradicting the studies of Aratani et al. (2009), who observed a more pronounced positive effect of no-tillage over conventional tillage. The WMD in the 0-0.05 m layer in the CTS was lower than in NTS only in the summer corn crop (2009/10). In this case, it can be affirmed that the greater disaggregation in CTS is due to the fact that, in tilled soils, aggregates are often exposed to physical disaggregation due to climate changes (wetting and drying processes), raindrop impact or to the activity of farm implements.
The soil managements led to decreases in the aggregation rates in all layers evaluated in both crop years, proving the loss of aggregate stability due to agricultural use in relation to native forest (NF) (Table 1). This was in agreement with the study of Silva et al. (2008), who observed that in all layers (0$0.10,0.10-0.20$ and $0.20-0.30 \mathrm{~m}$ ) the WMD was greater under NF than in areas under no-tillage. These results are similar to those found by Coutinho et al. (2010), who observed that, regardless of the depth in an Oxisol, the stability indices of WMD and MGD of the waterstable aggregates were highest in a cerrado area that had been gradually restored for 15 years after its use as pasture and was assumed as native. According to these authors, this behavior results from the greater input of plant material in that area, resulting in an increase in soil OM contents and, consequently, increased soil aggregation. Our results disagree with that study since, in the surface layer $(0-0.05 \mathrm{~m})$, the MGD and WMD indices in the NTS7 and in the NTS8 were similar to conventional tillage. This trend was also observed in the other soil layers, regardless of the crop year.

This behavior is thus opposed to the study of Hickmann et al. (2011) who reported that the no-tillage system increases aggregate stability in water since the MGD and WMD were superior in relation to the conventional tillage system. Organic matter and root development are the main agents responsible for the formation of larger aggregates (Salton et al., 2008); nevertheless, the stability of the aggregates is related to the cohesion among the soil particles. Thus, largersized aggregates may be obtained in some cases by the action of compression forces through the biological activity of roots and microorganisms (Carpenedo \& Mielniczuk, 1990).

The OM contents of the no-tillage system (2008/09) in the 0-0.10 m layer (Table 2) were lower than in the NF, with exception of NTS9 in the 0.05-0.10 m layer. It was observed that in the surface layer of the notillage systems in 2009/10, the OM contents were maintained in relation to 2008/09. However, in this sequence of comparison, a reduction in the soil OM contents can be observed in the 0.05-0.10 m layer. Thus, it becomes evident that the no-tillage systems were not efficient in increasing the $\mathrm{OM}$ content because, NTS5, NTS7 and NTS9 were similar to NTS6, NTS8 and NTS10 in the soil surface layer, respectively, in 2009/10. This is in contrast with the study of Costa Jr. et al. (2012), who observed a more significant contribution to carbon accumulation under NTS in the $0-5 \mathrm{~cm}$ soil layer. In the context of these authors, this is possibly due to the greater contact with the crop residues left on the surface, which are a source of organic matter in the soil.

Under conventional tillage, the $\mathrm{OM}$ content in the 0-0.05 m layer decreased from 2008/09 to 2009/10, corroborating a study of Ciotta et al. (2002), who predicted that the OM content would tend to decrease 
Table 1. Percentage of water-stable aggregates $>2.00 \mathrm{~mm}$ (Aggregation), mean geometric diameter (MGD) and weighted mean diameter (WMD) in four layers of a Red Oxisol, after different management periods and under native forest

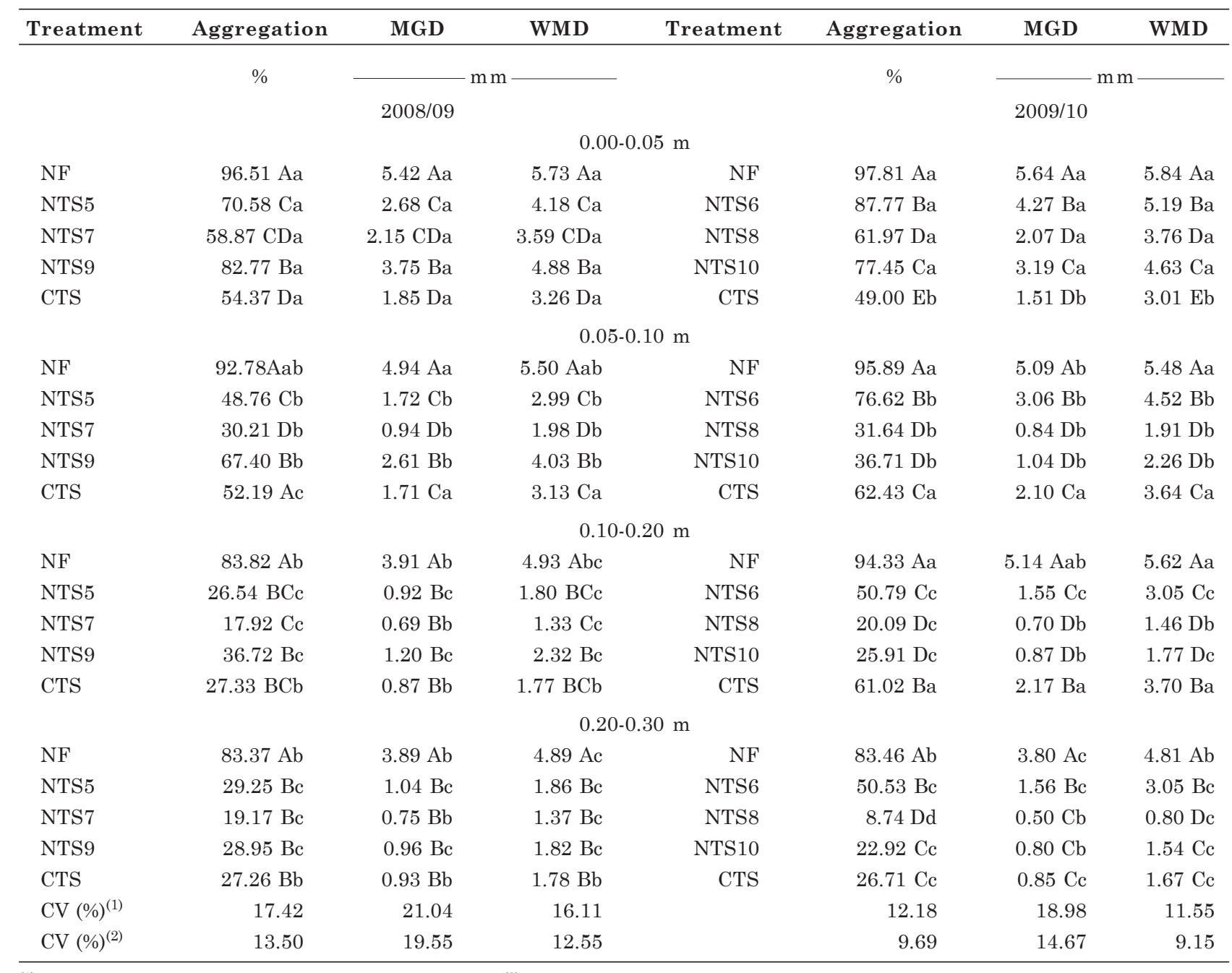

(1) Coefficient of variation of treatments (plots) and ${ }^{(2)}$ coefficient of variation for layers (split-plots). 2008/09 growing season: NF: native forest; NTS5: five-year no-tillage system; NTS7: seven-year no-tillage system; NTS9: nine-year no-tillage system; and CTS: conventional tillage system. 2009/10 growing season: NF: native forest; NTS6: six-year no-tillage system; NTS8: eight-year no-tillage system; NTS10: ten-year no-tillage system; and CTS: conventional tillage system in a Red Oxisol. Mean values followed by the same letter do not differ from each other by the Tukey test $(p<0.05)$. Upper-case letters indicate the comparison of soil properties in the same layer, and lower-case letters compare mean values of layers of the same soil property.

over the years since soil turnover in conventional tillage favors the microbial decomposition of $\mathrm{OM}$ through increasing aeration and temperature, as well as the fractionation and mixture of plant residues with the soil. It may be observed that the percentage of aggregates with a diameter greater than $2.00 \mathrm{~mm}$ in the $0-0.10 \mathrm{~m}$ layer in $2008 / 09$ was greater after nine years of no-tillage (NTS9), due to the higher contribution of OM contents than in the other periods of no-tillage. Nevertheless, in the 2009/10 growing season, the percentage of aggregates with a diameter greater than $2.00 \mathrm{~mm}$ decreased from NTS9 to NTS10 at this depth. This behavior in the 0-0.05 m layer may be explained by the rupture of the aggregates because of machine traffic at sowing and harvest, since the OM contents in NTS9 and NTS10 were maintained. The explanation for the percentage of aggregate diameter greater than $2.00 \mathrm{~mm}$ in the 0.05 $0.10 \mathrm{~m}$ layer is the decreased MO content.

In general, considering the variables aggregate percentage $>2.00 \mathrm{~mm}, \mathrm{MGD}$ and WMD, the aggregate stability was generally greater under NF in relation to the other treatments. For their part, the NTS treatments, especially the NTS9 (2008/09), tended to greater MGD and WMD in relation to the CTS in the 0-0.10 m layer (Table 1). In other words, in this layer, soil turnover reduces aggregate stability. These variables thereby allowed the systems to be qualified from the point of view of aggregate stability, i.e., analyze the variables as indicators of the physical 
Table 2. Organic matter content in four layers of a Red Oxisol after different management periods and under native forest

\begin{tabular}{|c|c|c|c|c|c|c|c|c|c|c|}
\hline \multirow{3}{*}{ Layer } & \multicolumn{10}{|c|}{ Organic matter } \\
\hline & \multicolumn{5}{|c|}{$2008 / 09$} & \multicolumn{5}{|c|}{$2009 / 10$} \\
\hline & NF & NTS5 & NTS7 & NTS9 & CTS & NF & NTS6 & NTS8 & NTS10 & CTS \\
\hline \multicolumn{11}{|l|}{$\mathrm{m}$} \\
\hline $0.00-0.05$ & $33.0 \mathrm{Aa}$ & $16.5 \mathrm{Ca}$ & $17.5 \mathrm{Ca}$ & $23.5 \mathrm{Ba}$ & $16.5 \mathrm{Ca}$ & $28.3 \mathrm{Aa}$ & $19.0 \mathrm{Ca}$ & $19.0 \mathrm{Ca}$ & $24.3 \mathrm{Ba}$ & 13.8 Dab \\
\hline $0.05-0.10$ & $26.0 \mathrm{Ab}$ & $12.5 \mathrm{Bab}$ & 15.5 Bab & $22.0 \mathrm{Aa}$ & $16.5 \mathrm{Ba}$ & $23.5 \mathrm{Ab}$ & $12.8 \mathrm{Cb}$ & $12.8 \mathrm{Cb}$ & $17.0 \mathrm{Bb}$ & $14.0 \mathrm{BCa}$ \\
\hline $0.10-0.20$ & $17.5 \mathrm{Ac}$ & $12.0 \mathrm{Bb}$ & 16.5 ABab & $17.5 \mathrm{Ab}$ & $14.5 \mathrm{ABa}$ & $18.5 \mathrm{Ac}$ & $12.1 \mathrm{Bb}$ & $11.6 \mathrm{Bb}$ & $12.3 \mathrm{Bc}$ & 12.3 Bab \\
\hline $0.20-0.30$ & 16.0 Ac & $10.5 \mathrm{Bb}$ & $13.0 \mathrm{ABb}$ & $15.5 \mathrm{ABb}$ & $12.5 \mathrm{ABa}$ & $13.6 \mathrm{Ad}$ & $12.5 \mathrm{ABb}$ & $9.0 \mathrm{Bc}$ & $11.1 \mathrm{ABc}$ & $11.4 \mathrm{ABb}$ \\
\hline \multicolumn{4}{|c|}{$\mathrm{CV}^{(1)}=13.72 \%$} & \multicolumn{2}{|c|}{$\mathrm{CV}^{(2)}=8.06 \%$} & \multicolumn{2}{|c|}{$\mathrm{CV}^{(1)}=19.20 \%$} & & \multicolumn{2}{|c|}{$\mathrm{CV}^{(2)}=8.80 \%$} \\
\hline
\end{tabular}

(1) Coefficient of variation of treatments (plots) and ${ }^{(2)}$ coefficient of variation for layers (split-plots). 2008/09 growing season: NF: native forest; NTS5: five-year no-tillage system; NTS7: seven-year no-tillage system; NTS9: nine-year no-tillage system; and CTS: conventional tillage system. 2009/10 growing season: NF: native forest; NTS6: six-year no-tillage system; NTS8: eight-year no-tillage system; NTS10: ten-year no-tillage system; and CTS: conventional tillage system in a Red Oxisol. Mean values followed by the same letter do not differ from each other by the Tukey test $(\mathrm{p}<0.05)$. Upper-case letters indicate the comparison of soil properties in the same layer, and lower-case letters compare mean values of layers of the same soil property.

quality of the soil. In this aspect, according to all the results mentioned previously, it may be affirmed that the $0-0.10 \mathrm{~m}$ layer was the most susceptible to evaluate alterations in these variables in this soil.

In the 2008/09 growing season, the macroporosity of NTS7 and the NTS9, in the 0-0.05 and 0.05-0.10 m layers, respectively, were similar to the CTS and the NF. However, in the 2009/10 growing season in the same areas, when they were denominated NTS8 and NTS10, a decline was observed in the NTS8, and the NTS10 maintained the volume of macropores in comparison to the previous growing season in the same layers (Table 3). According to Cunha et al. (2007), soil porosity in the no-tillage system may be favored by rotations that include a greater number of soybean crops.

The macroporosity in the 0-0.10 m layer of NTS5 $\left(0.095\right.$ and $\left.0.090 \mathrm{~m}^{3} \mathrm{~m}^{-3}\right)$, in the $0-0.05 \mathrm{~m}$ and 0.10 $0.30 \mathrm{~m}$ layers of NTS9 $\left(0.083,0.097\right.$ and $\left.0.067 \mathrm{~m}^{3} \mathrm{~m}^{-3}\right)$, and in the $0.05-0.10 \mathrm{~m}$ layer of NTS7 $\left(0.086 \mathrm{~m}^{3} \mathrm{~m}^{-3}\right)$ in the $2008 / 09$ growing season was near $0.10 \mathrm{~m}^{3} \mathrm{~m}^{-3}$, the minimum adequate for the liquid and gas exchanges between the external environment and the soil, and that considered critical for root growth of most crops (Baver et al., 1972). The NTS8 in the layer 0-0.05 m $\left(0.082 \mathrm{~m}^{3} \mathrm{~m}^{-3}\right)$ and NTS10 in the 0.05-0.10, 0.10-0.20 and $0.20-0.30$ m layers $\left(0.085,0.084\right.$ and $0.091 \mathrm{~m}^{3} \mathrm{~m}^{-3}$, respectively) in the 2009/10 growing season are also near this critical volume of macroporosity. Thus, when the NTS9 treatment came to be NTS10 in the 2009/10 growing season, a reduction was observed in the interval from 0.05 to $0.20 \mathrm{~m}$ depth in terms of soil macroporosity, however, with no significant difference for the 0.10-0.20 m layer.

According to Silva et al. (2005), soil turnover normally promotes a temporary increase of macroporosity when compared to the no-tillage system. Nevertheless, the same authors claim that this effect is eliminated by the reconsolidation or densification of the soil. Greater microporosity (Table 3) was recorded in the soil under NTS9 and NTS5 in the 0-0.30 m layer in comparison to the NTS7 (2008/09 growing season) because, according to Reichert et al. (2007), the macropores, responsible for soil aeration, shrink during soil densification and are replaced by micropores. The lower micropore volume in the 2008/09 growing season of the NTS7, in the 0-0.05 m and $0.10-0.30 \mathrm{~m}$ layers, led to an increase in soil microporosity when it came to be NTS8 in the 2009/10 growing season.

Soil bulk density in the 0-0.05 m layer of the CTS was significantly lower than in the no-tillage system; however, it did not differ from the NTS7 (2008/09 growing season). However, in the corn succession cycle in the following year, the CTS showed similar behavior and was inferior only to NTS8 in comparison to the other no-tillage treatments. According to Silva et al. (2005), greater BD in the surface layer of the no-tillage system in relation to the CTS are often observed and are due to densification as a result of the lack of turnover, as well as the compaction induced by machine traffic. A similar fact was reported in a study of Tavares Filho et al. (2012), where the BD of an Alfisol in an 11-year no-tillage management was $4.2 \%$ greater in relation to no-tillage management with chisel plowing every four years. The treatment with chisel plowing provided a $40.8 \%$ greater macroporosity than the treatment with only no-tillage.

This behavior was also mentioned by Tavares Filho et al. (2006) in an analysis of the effects of chisel plowing on the physical properties of a dystroferric Red Oxisol under no-tillage for more than 20 years. However, according to Silva et al. (2012), the beneficial effect of chisel plowing in reducing BD is of a temporary nature because it was observed that after six months of CTS, soil BD increased by $20 \%$ and this behavior remained stable in the following year, tending to a stabilized state. 
Table 3. Macroporosity (Mac), microporosity (Mic) and bulk density (BD) in four layers of a Red Oxisol after different management periods and under native forest

\begin{tabular}{|c|c|c|c|c|c|c|c|}
\hline Treatment & Mac & Mic & BD & Treatment & Mac & Mic & BD \\
\hline & \multicolumn{2}{|c|}{$-\mathrm{m}^{3} \mathrm{~m}^{-3}$} & \multirow[t]{2}{*}{$\mathrm{Mg} \mathrm{m}^{-3}$} & & \multicolumn{2}{|c|}{$\longrightarrow \mathrm{m}^{3} \mathrm{~m}^{-3}$} & \multirow[t]{2}{*}{$\mathrm{Mg} \mathrm{m}^{-3}$} \\
\hline & & $2008 / 09$ & & & & $2009 / 10$ & \\
\hline \multicolumn{8}{|c|}{$0.00-0.05 \mathrm{~m}$} \\
\hline NF & $0.212 \mathrm{Aa}$ & $0.238 \mathrm{BCb}$ & $1.30 \mathrm{Db}$ & $\mathrm{NF}$ & $0.316 \mathrm{Aa}$ & $0.257 \mathrm{Cc}$ & $1.16 \mathrm{Cc}$ \\
\hline NTS5 & $0.095 \mathrm{Ba}$ & $0.277 \mathrm{Aa}$ & $1.69 \mathrm{Aa}$ & NTS6 & $0.179 \mathrm{Ba}$ & $0.301 \mathrm{Ba}$ & $1.54 \mathrm{Bb}$ \\
\hline NTS7 & $0.179 \mathrm{Aa}$ & $0.227 \mathrm{Cb}$ & $1.50 \mathrm{BCb}$ & NTS8 & $0.082 \mathrm{Ca}$ & $0.345 \mathrm{Aa}$ & $1.76 \mathrm{Aa}$ \\
\hline NTS9 & $0.083 \mathrm{Ba}$ & $0.304 \mathrm{Aa}$ & $1.60 \mathrm{ABa}$ & NTS10 & $0.117 \mathrm{BCa}$ & $0.351 \mathrm{Aa}$ & $1.61 \mathrm{ABb}$ \\
\hline CTS & $0.234 \mathrm{Aa}$ & $0.251 \mathrm{Ba}$ & $1.39 \mathrm{CDa}$ & CTS & $0.267 \mathrm{Aa}$ & $0.260 \mathrm{Cb}$ & $1.42 \mathrm{Bb}$ \\
\hline \multicolumn{8}{|c|}{$0.05-0.10 \mathrm{~m}$} \\
\hline NF & $0.178 \mathrm{Aab}$ & $0.247 \mathrm{Cab}$ & $1.46 \mathrm{Ca}$ & $\mathrm{NF}$ & $0.234 \mathrm{Ab}$ & $0.270 \mathrm{Cbc}$ & $1.38 \mathrm{Bb}$ \\
\hline NTS5 & $0.090 \mathrm{Ba}$ & $0.275 \mathrm{Aa}$ & $1.66 \mathrm{ABa}$ & NTS6 & $0.103 \mathrm{Bb}$ & $0.325 \mathrm{ABa}$ & $1.77 \mathrm{Aa}$ \\
\hline NTS7 & $0.086 \mathrm{Bb}$ & $0.253 \mathrm{BCa}$ & $1.75 \mathrm{Aa}$ & NTS8 & $0.124 \mathrm{Ba}$ & $0.302 \mathrm{BCb}$ & $1.82 \mathrm{Aa}$ \\
\hline NTS9 & $0.126 \mathrm{ABa}$ & $0.288 \mathrm{Ab}$ & $1.55 \mathrm{BCa}$ & NTS10 & $0.085 \mathrm{Ba}$ & $0.346 \mathrm{Aa}$ & $1.76 \mathrm{Aa}$ \\
\hline CTS & $0.190 \mathrm{Aab}$ & $0.264 \mathrm{Ba}$ & $1.45 \mathrm{Ca}$ & CTS & $0.224 \mathrm{Aa}$ & $0.267 \mathrm{Cab}$ & $1.53 \mathrm{Ab}$ \\
\hline \multicolumn{8}{|c|}{$0.10-0.20 \mathrm{~m}$} \\
\hline NF & $0.150 \mathrm{Aab}$ & $0.252 \mathrm{Ba}$ & $1.53 \mathrm{Aa}$ & $\mathrm{NF}$ & $0.145 \mathrm{Ac}$ & $0.306 \mathrm{ABa}$ & $1.62 \mathrm{Aa}$ \\
\hline NTS5 & $0.120 \mathrm{Aa}$ & $0.260 \mathrm{Ba}$ & $1.58 \mathrm{Aa}$ & NTS6 & $0.106 \mathrm{Ab}$ & $0.302 \mathrm{ABa}$ & $1.76 \mathrm{Aa}$ \\
\hline NTS7 & $0.111 \mathrm{Aab}$ & $0.235 \mathrm{Cb}$ & $1.66 \mathrm{Aa}$ & NTS8 & $0.141 \mathrm{Aa}$ & $0.279 \mathrm{Bb}$ & $1.75 \mathrm{Aa}$ \\
\hline NTS9 & $0.097 \mathrm{Aa}$ & $0.300 \mathrm{Aa}$ & $1.56 \mathrm{Aa}$ & NTS10 & $0.084 \mathrm{Aa}$ & $0.331 \mathrm{Aa}$ & $1.76 \mathrm{Aa}$ \\
\hline CTS & $0.150 \mathrm{Ab}$ & $0.257 \mathrm{Ba}$ & $1.52 \mathrm{Aa}$ & CTS & $0.148 \mathrm{Ab}$ & $0.291 \mathrm{Bab}$ & $1.69 \mathrm{Aa}$ \\
\hline \multicolumn{8}{|c|}{$0.20-0.30 \mathrm{~m}$} \\
\hline NF & $0.125 \mathrm{ABb}$ & $0.257 \mathrm{BCa}$ & $1.56 \mathrm{ABa}$ & $\mathrm{NF}$ & $0.180 \mathrm{Abc}$ & $0.297 \mathrm{ABab}$ & $1.58 \mathrm{Ba}$ \\
\hline NTS5 & $0.107 \mathrm{ABa}$ & $0.268 \mathrm{Ba}$ & $1.60 \mathrm{ABa}$ & NTS6 & $0.131 \mathrm{ABab}$ & $0.299 \mathrm{ABa}$ & $1.72 \mathrm{ABa}$ \\
\hline NTS7 & $0.109 \mathrm{ABab}$ & $0.228 \mathrm{Cb}$ & $1.68 \mathrm{Aa}$ & NTS8 & $0.138 \mathrm{ABa}$ & $0.277 \mathrm{Bb}$ & $1.79 \mathrm{Aa}$ \\
\hline NTS9 & $0.067 \mathrm{Ba}$ & $0.317 \mathrm{Aa}$ & $1.60 \mathrm{ABa}$ & NTS10 & $0.091 \mathrm{Ba}$ & $0.329 \mathrm{Aa}$ & $1.74 \mathrm{ABab}$ \\
\hline CTS & $0.173 \mathrm{Aab}$ & $0.249 \mathrm{Ba}$ & $1.48 \mathrm{Ba}$ & CTS & $0.147 \mathrm{ABb}$ & $0.299 \mathrm{ABa}$ & $1.71 \mathrm{ABa}$ \\
\hline CV $(\%)^{(1)}$ & 22.39 & 14.05 & 16.04 & 19.84 & 17.08 & 18.28 & \\
\hline $\mathrm{CV}(\%)^{(2)}$ & 24.36 & 17.15 & 14.13 & 18.50 & 16.19 & 14.80 & \\
\hline
\end{tabular}

(1) Coefficient of variation of treatments (plots) and ${ }^{(2)}$ coefficient of variation for layers (split-plots). 2008/09 growing season: NF: native forest; NTS5: five-year no-tillage system; NTS7: seven-year no-tillage system; NTS9: nine-year no-tillage system; and CTS: conventional tillage system. 2009/10 growing season: NF: native forest; NTS6: six-year no-tillage system; NTS8: eight-year no-tillage system; NTS10: ten-year no-tillage system; and CTS: conventional tillage system in a Red Oxisol. Mean values followed by the same letter do not differ from each other by the Tukey test $(\mathrm{p}<0.05)$. Upper-case letters indicate the comparison of soil properties in the same layer, and lower-case letters compare mean values of layers of the same soil property.

Thus, it can be seen that conventional tillage (CTS) raised macroporosity to values above $0.10 \mathrm{~m}^{3} \mathrm{~m}^{-3}$ (Table 3), which are similar results to those of native forest (NF). On the one hand, MGD and WMD were lower under conventional tillage, especially when compared to NTS9 (2008/09) and NTS6 (2009/10) in the $0-0.10 \mathrm{~m}$ layer, probably leading to clod breaking and cutting of remaining roots (Table 1). On the other hand, it induced decompaction, leading to macroporosity at adequate levels. Therefore, based on the results of the variables soil BD and macro- and microporosity, their use as indicators of soil physical quality can be confirmed. The entire depth range assessed in this study, i.e., the soil layer from $0-0.30 \mathrm{~m}$, was relevant for identifying the susceptibility of these variables under the experimental conditions, especially when considering that critical values of macroporosity near $0.10 \mathrm{~m}^{3} \mathrm{~m}^{-3}$ were diagnosed throughout this layer.

Water retention (WRC) was highest in all layers in NTS9 and NTS10, respectively, in the 2008/09 and 2009/10 growing seasons at tensions above $0.006 \mathrm{MPa}$ (Figures 1 and 2). The reason for this was the high microporosity in this treatment (Table 3), in agreement with Araújo et al. (2004), who found an increase in $\mathrm{BD}$ and, consequently, an increase in water retention, i.e., a change in the distribution of pore sizes, favoring smaller-diameter pores. This result was also reported by Betioli Jr. et al. (2012), who observed that the WRC was significant and positively influenced by the BD of a Red Oxisol after 30 years under notillage. 


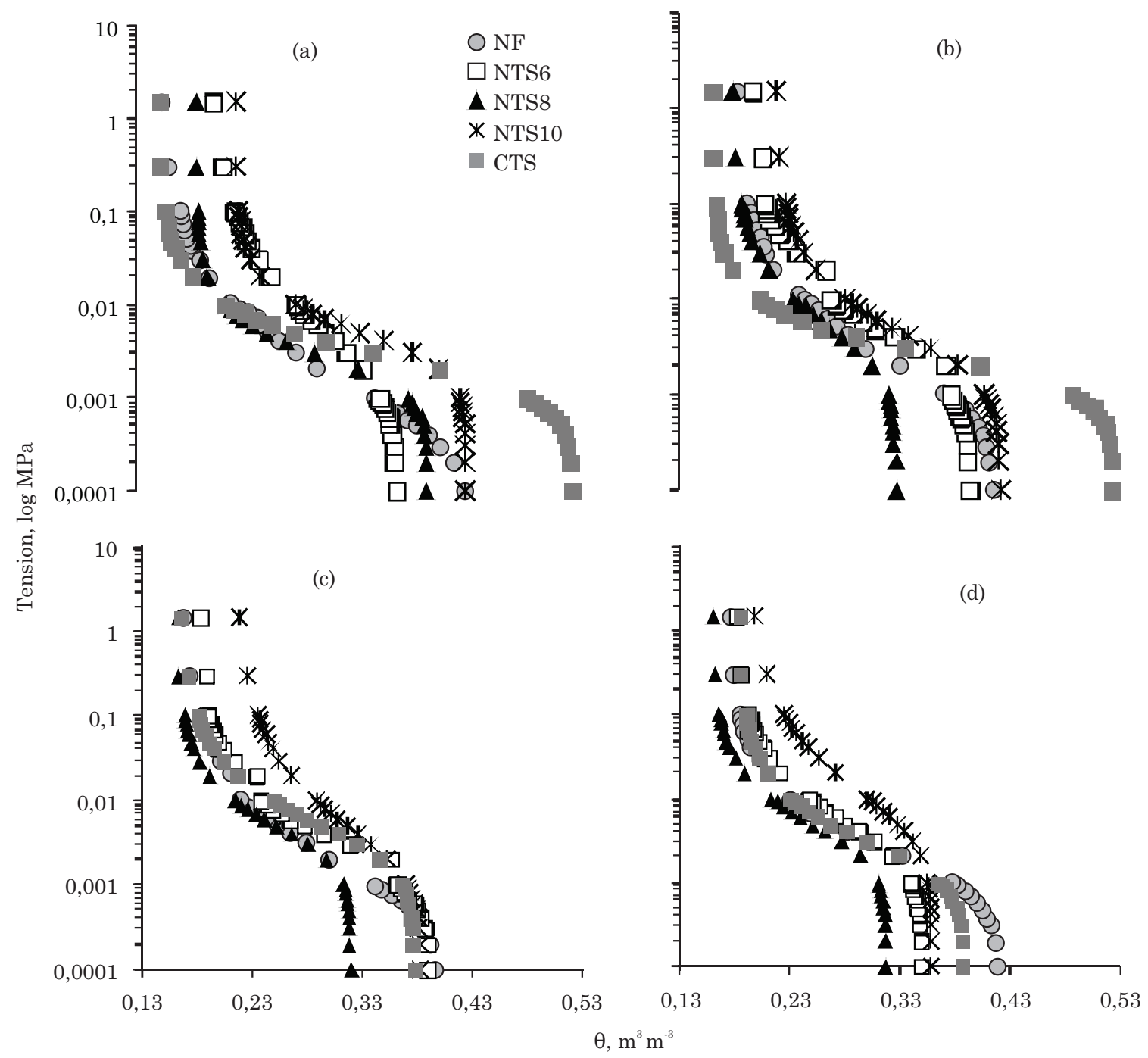

Figure 1. Water retention curves of a Red Oxisol in different layers. (a) 0-0.05 m, (b) 0.05-0.10 m, (c) 0.10-0.20 $\mathrm{m}$ and (d) 0.20-0.30 m. 2008/09 growing season - NF: native forest, NTS5: five-year no-tillage, NTS7: seven-year no-tillage, NTS9: nine-year no-tillage, and CTS: conventional tillage system.

According to Reichert et al. (2007), an increase in microporosity makes the soil more efficient in water retention, while an increase in the proportion of macroporosity is responsible for aeration and water drainage. Beutler et al. (2002), studying water retention in Oxisols under different land use and management systems, observed greater retention at all soil water tensions of the cultivated soil in comparison to soil under NF. Likewise, Silva et al. (2008) confirmed that water retention in the $\mathrm{PD} 6>\mathrm{NF}>\mathrm{PD} 4>\mathrm{PD} 2$ in the $0-0.30 \mathrm{~m}$ layer followed the same decreasing order in terms of soil microporosity. When soil dries, the mass of solids per unit of area increases, expressed by the increase in $\mathrm{BD}$, which contributed to the increase in moisture due to greater water adsorption and greater volume of pores with reduced diameter (Blainski et al., 2009).

In general, the $\mathrm{S}$ index (Table 4) increased from the 2008/09 growing season (NTS5, NTS7 and NTS9) to the 2009/10 growing season (NTS6, NTS8 and NTS10) in all layers, with the exception of the 0.10$0.20 \mathrm{~m}$ layer when the NTS5 and the NTS6 are compared, and also in the 0-0.05 m layer when comparing NTS7 with NTS8 and NTS9 with NTS10. It may thus be affirmed that in these periods, the maintenance of macroporosity $(0.05-0.30 \mathrm{~m})$ and of organic matter (0-0.05 and 0.20-0.30 m), may have been responsible for an improved soil structure, which in turn contributed positively to the $\mathrm{S}$ index. It may be seen that the increase in the period of adoption of the no-tillage system, together with the repetitive effect of machine traffic, had no negative effect on the soil structure. In a similar situation, Cavalieri et al. (2009) affirmed that the soil structure was well-preserved after 14 years of no-tillage in a Rhodic Ferrasol.

The greatest values of the $\mathrm{S}$ index were observed in the CTS in the 0-0.05 m layer (0.106) and 0.05- 


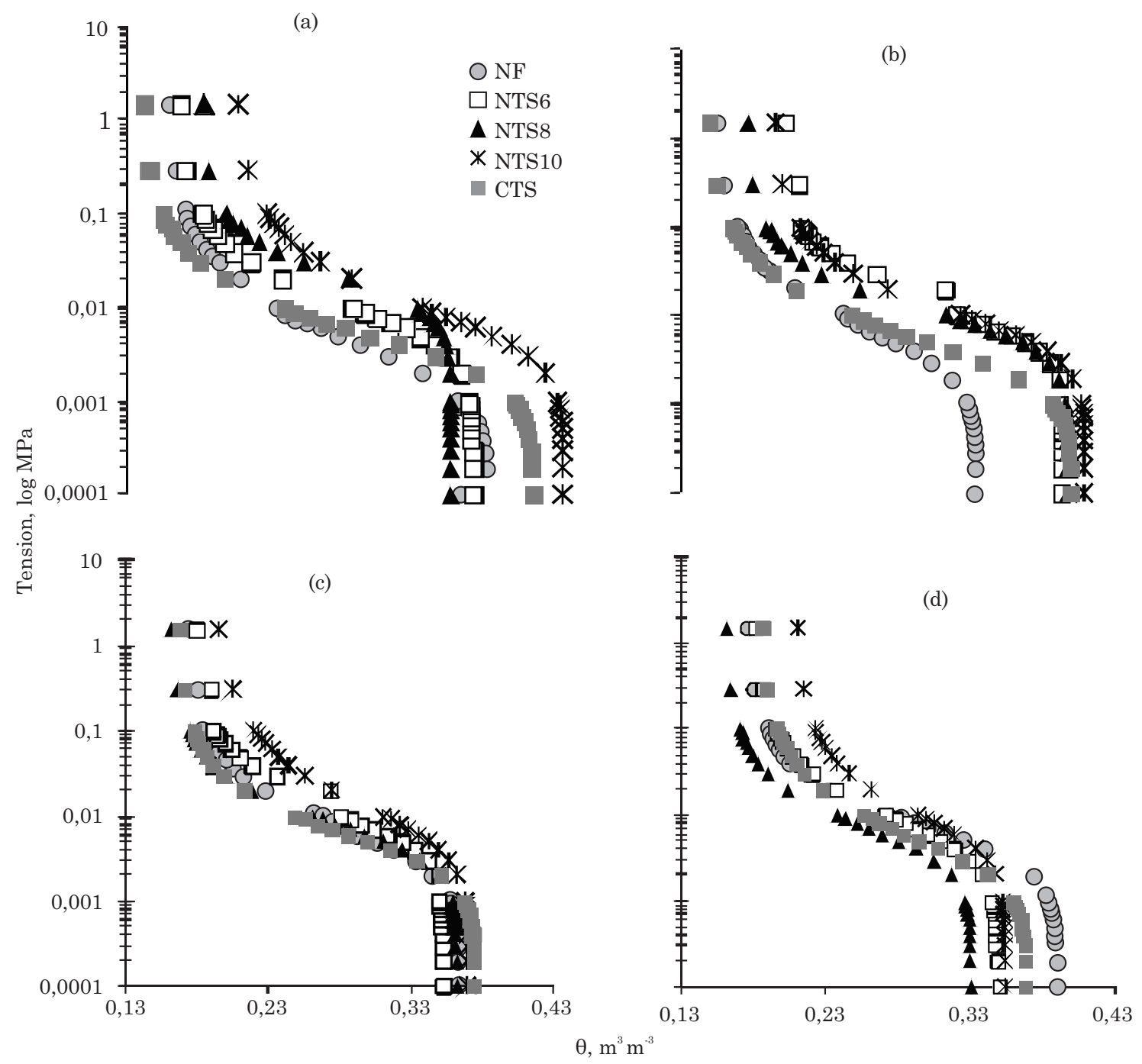

Figure 2. Water retention curves of a Red Oxisol in different layers. (a) 0-0.05 m, (b) 0.05-0.10 m, (c) 0.10-0.20 $m$ and (d) 0.20-0.30 m. 2009/10 growing season - NF: native forest, NTS6: six-year no-tillage, NTS8: eightyear no-tillage, NTS10: ten-year no-tillage, and CTS: conventional tillage system.

$0.10 \mathrm{~m}$ layer (0.099) in the 2008/09 growing season, and in the 0-0.05 m layer $(0,066)$ in 2009/10. This fact may be associated with soil turnover, resulting in high macroporosity in this treatment. Also, a reduction in the S index was observed at greater depth, with the exception of the 0.10-0.30 m layer in the 2009/10 growing season. This shows that the 0-0.05 $\mathrm{m}$ layer probably has better physical conditions for root growth. In some layers of certain treatments, most of the values of the $S$ index were greater $\geq 0.035$, a value considered a threshold between soil with degraded and with non-degraded physical structure (Dexter, 2004). This result agrees with the findings of Angelotti Netto et al. (2007), in a Red Oxisol under different land use and management systems. They noted that this behavior was observed in a clayey Red Oxisol, even when exposed to the loss of physical quality due to machine and equipment traffic. Most values were $\geq 0.045$, a limit considered the most adequate for tropical soils, according to Andrade \& Stone (2009).

In contrast, Tormena et al. (2008), evaluating the S index under no-tillage and conventional tillage in a Typic Hapludox, in the row and between rows of corn, reported that the values of this index are greatest under no-tillage and in the plant row. The same authors concluded that the $\mathrm{S}$ index decreases as BD increases. In another situation, Streck et al. (2008) confirmed that the $\mathrm{S}$ index was greater in soil under forest cover than in a no-tillage system. According to these authors, the greater $\mathrm{S}$ value in the forest indicates a better pore distribution and, therefore, less physical restrictions to root growth, be it through aeration or mechanical restriction or through variables of water retention. This is in agreement with Silva et al. (2008) and Cunha et al. (2012), who also observed that the soil under native forest has a better structural quality than cultivated soil. 
The analysis by the $\mathrm{S}$ index requires some caution because in our study, after observing the total mean values of each treatment (Table 4), the cropped area was indicated as having better quality, even better that the proper native forest area. In 2008/09, the following decreasing order of this index was found: CTS $>$ NF $>$ NTS9 $>$ NTS7 > NTS5. In 2009/10 it was: CTS $>$ NTS $8=$ NTS10 $>$ NTS6. This behavior indicates that the mean value of the $\mathrm{S}$ index of CTS in 2008/09 resulted in a value 4.84 times greater than that of $\mathrm{NF}$ and, in 2009/10, this comparison value was 1.12 times greater. As this index has no physical significance and is always presented without a physical unit, these results would allow the conclusion that the conventional system is the one with the best quality, even better than native forest, contradicting the general understanding of this matter. This shows that the absolute quality indicator ( $\mathrm{S}$ index) was insufficient to describe the system, so that another indicator was needed for interpretation macroporosity. This reaffirms the warning of Jong van Lier (2012) that the S index must be applied with caution. According to this author, the value of this index as an indicator, in absolute terms, does not determine the physical quality of a soil. Since in order to obtain the $\mathrm{S}$ index it is necessary to determine the soil moisture curve, fit the van Genuchten equation, and obtain the second derivative, a simpler route is suggested, which is the determination of soil porosity.

Greater values of $\mathrm{K} \theta$ were obtained in the soil under NF and, in the 2009/10 growing season, NF only differed from NTS10 (Figure 3), agreeing with the results of Stone et al. (2002), who attributed this to the greater number of pores in NF. The same authors observed that the reducing effect of compaction on the size of the pores that transport water explains the reduction of $\mathrm{K} \theta$ with the increase of BD. Similarly, Fontenele et al. (2009) reported that the water infiltration rate in a Yellow Oxisol in native cerrado was around four times greater $\left(356.0 \mathrm{~mm} \mathrm{~h}^{-1}\right)$ than in a three-year no-tillage system under soybean in the summer $\left(86.7 \mathrm{~mm} \mathrm{~h}^{-1}\right)$, and six times in relation to conventional soil tillage $\left(57.3 \mathrm{~mm} \mathrm{~h}^{-1}\right)$. According to these authors, this behavior may be explained by the lower BD in the native cerrado and greater stability of aggregation due to the maintenance of the original structure, with a greater quantity of macroaggregates.

The water infiltration rate in the soil is extremely important because greater infiltration contributes to reduce the surface runoff, avoiding the occurrence of soil erosion. According to Reichardt \& Timm (2012), saturated hydraulic conductivity of the soil $(\mathrm{K} \theta)$ varies greatly from soil to soil and even within the same soil class, depending on the porous space. Thus, this variation may be caused by an external charge/load and may change the soil structure, or through the effect of the expansivenesss of clays or densification of the soil layers brought about by the finer particles conducted by water movement (Bear, 1979).

In another situation, Castro et al. (2009) concluded that eight years of NTS under corn induced a greater $\mathrm{K} \theta$, to a depth of $0.20 \mathrm{~m}$ in a Rhodic Hapludox, due to greater pore continuity in this system when compared to conventionally tilled systems. This behavior was also reported by Silva et al. (2012), who observed that a treatment of 18 years of no-tillage alfalfa-corn rotation increased the hydraulic conductivity in a Oxisol in the 0.05-0.10 $\mathrm{m}_{\text {layer }}\left(170 \mathrm{~mm} \mathrm{~h}^{-1}\right)$ and 0.10 $0.20 \mathrm{~m}^{2}$ layer $\left(147 \mathrm{~mm} \mathrm{~h}^{-1}\right)$. According to these authors, the results were consistent with the macroporosity data and with possible beneficial effects on soil water infiltration and reduction of surface runoff.

Nevertheless, no differences were observed in K $\theta$ within the CTS and the different time periods of

Table 4. S Index of the Red Oxisol according to periods of managements and native forest, in four layers

\begin{tabular}{|c|c|c|c|c|c|c|c|c|c|c|}
\hline \multirow{3}{*}{ Layer } & \multicolumn{10}{|c|}{$\mathrm{S}$ index } \\
\hline & \multicolumn{5}{|c|}{ 2008/09 } & \multicolumn{5}{|c|}{$2009 / 10$} \\
\hline & NF & NTS5 & NTS7 & NTS9 & CTS & NF & NTS6 & NTS8 & NTS10 & CTS \\
\hline \multicolumn{11}{|l|}{$\mathrm{m}$} \\
\hline $0.00-0.05$ & $0.049 \mathrm{Ba}$ & $0.020 \mathrm{Cb}$ & $0.047 \mathrm{Ba}$ & $0.047 \mathrm{Ba}$ & $0.106 \mathrm{Aa}$ & $0.054 \mathrm{Ba}$ & $0.049 \mathrm{Ba}$ & $0.041 \mathrm{Ba}$ & $0.050 \mathrm{Ba}$ & $0.066 \mathrm{Aa}$ \\
\hline $0.05-0.10$ & $0.086 \mathrm{Ba}$ & $0.030 \mathrm{Ca}$ & $0.021 \mathrm{Dc}$ & $0.037 \mathrm{Cb}$ & $0.099 \mathrm{Ab}$ & $0.036 \mathrm{Bb}$ & $0.038 \mathrm{ABb}$ & $0.046 \mathrm{Aab}$ & $0.047 \mathrm{Aa}$ & $0.049 \mathrm{Ab}$ \\
\hline $0.10-0.20$ & $0.036 \mathrm{Bd}$ & $0.031 \mathrm{BCa}$ & $0.031 \mathrm{BCb}$ & $0.027 \mathrm{Cc}$ & $0.043 \mathrm{Ac}$ & $0.039 \mathrm{ABb}$ & $0.034 \mathrm{ABb}$ & $0.041 \mathrm{Aab}$ & $0.034 \mathrm{Bb}$ & $0.048 \mathrm{ABa}$ \\
\hline $0.20-0.30$ & $0.070 \mathrm{Ab}$ & $0.027 \mathrm{CDa}$ & $0.030 \mathrm{Cb}$ & $0.023 \mathrm{Dc}$ & $0.044 \mathrm{Bc}$ & $0.051 \mathrm{Aa}$ & $0.032 \mathrm{Bb}$ & $0.037 \mathrm{Bb}$ & $0.033 \mathrm{Bb}$ & $0.039 \mathrm{Ba}$ \\
\hline Mean & 0.060 & 0.027 & 0.032 & 0.033 & 0.292 & 0.045 & 0.038 & 0.041 & 0.041 & 0.050 \\
\hline \multicolumn{4}{|c|}{$\mathrm{CV}^{(1)}=19.75 \%$} & \multicolumn{2}{|c|}{$\mathrm{CV}^{(2)}=9.98 \%$} & \multicolumn{2}{|c|}{$\mathrm{CV}^{(1)}=18.61 \%$} & & \multicolumn{2}{|c|}{$\mathrm{CV}^{(2)}=13.06 \%$} \\
\hline
\end{tabular}

(1) Coefficient of variation of treatments (plots) and ${ }^{(2)}$ coefficient of variation for layers (split-plots). 2008/09 growing season: NF: native forest; NTS5: five-year no-tillage system; NTS7: seven-year no-tillage system; NTS9: nine-year no-tillage system; and CTS: conventional tillage system. 2009/10 growing season: NF: native forest; NTS6: six-year no-tillage system; NTS8: eight-year no-tillage system; NTS10: ten-year no-tillage system; and CTS: conventional tillage system in a Red Oxisol. Mean values followed by the same letter do not differ from each other by the Tukey test $(p<0.05)$. Upper-case letters indicate the comparison of soil properties in the same layer, and lower-case letters compare mean values of layers of the same soil property. 


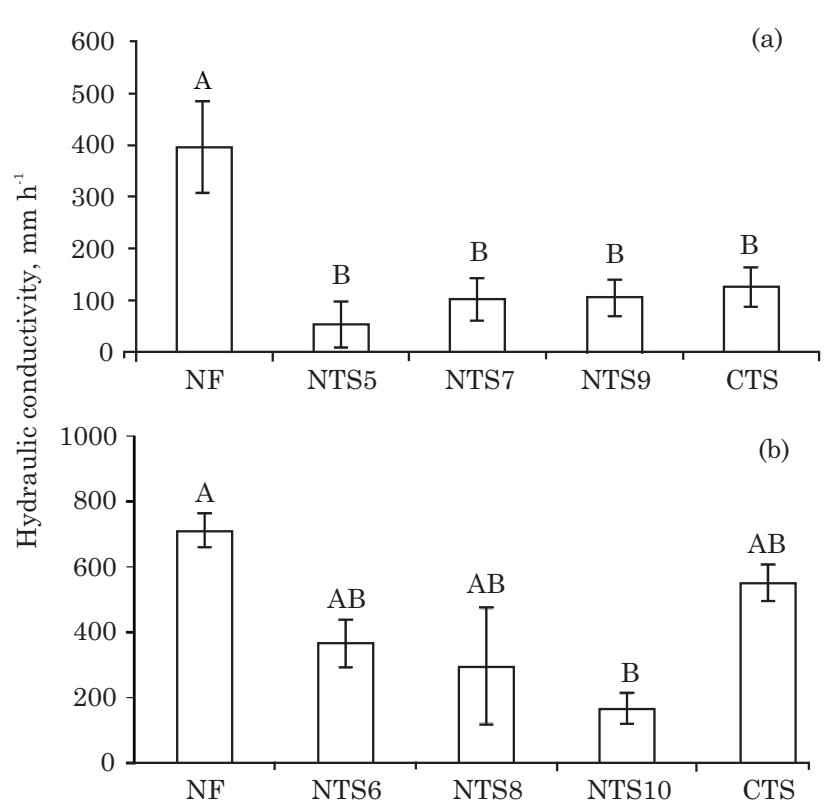

Figure 3. Saturated hydraulic conductivity of a Red Oxisol under soybean (a) (2008/09 growing season) - NF: native forest, NTS5: five-year notillage system, NTS7: seven-year no-tillage system, NTS9: nine-year no-tillage system, and CTS: conventional tillage system; and of corn (b) (2009/10 growing season) - NF: native forest, NTS6: six-year no-tillage system, NTS8: eightyear no-tillage system, NTS10: ten-year no-tillage system, and CTS: conventional tillage system. The bars indicate the mean standard errors.

no-tillage adoption in the two growing seasons (Figure 3). However, the absolute hydraulic conductivity was higher in NTS6, NTS8 and CTS in $2009 / 10$ than in the previous growing season, i.e., similar conditions as of NF. In a Red Yellow Oxisol, Silva \& Kato (1997) found important differences in saturated hydraulic conductivity between no-tillage and conventional management, showing that small differences in macroporosity were accompanied by large differences in $\mathrm{K} \theta$. In a Rhodic Ferralsol under conventional tillage, Cássaro et al. (2011) observed that principally this management promoted the greatest modifications in WRC in the soil surface. The same authors affirmed that this behavior shows that it is easier to remove water from the surface than from the subsurface layer.

\section{CONCLUSIONS}

1. Distinct time periods since the application of soil managements can be differentiated by the variables saturated hydraulic conductivity, aggregate stability, bulk density, and macro- and microporosity, which proved effective as indicators of the soil physical quality of the soil.
2. In this study, the use of the $\mathrm{S}$ index alone is not recommended as an exclusive indicator of soil physical quality as it is insufficient to discriminate the treatments because another indicator, such as macroporosity, was necessary for the interpretation, even though the $\mathrm{S}$ index was greater than 0.035 .

\section{ACKNOWLEDGEMENT}

The authors wish to thank the Fundação de Amparo à Pesquisa do Estado de São Paulo (FAPESP) for a postgraduate scholarship to the first author.

\section{LITERATURE CITED}

ANDRADE, R.S. \& STONE, L. Índice S como indicador da qualidade física de solos do cerrado brasileiro. R. Bras. Eng. Agríc. Amb., 13:382-388, 2009.

ANGELOTTI NETTO, A.; FERNANDES, E.J. \& CENTURION, J.F. Propriedades físicas e indicador de qualidade de um Latossolo Vermelho submetido a diferentes sistemas de uso e manejo. Irriga, 12:27-37, 2007.

ARATANI, R.G.; FREDDI, O.S.; CENTURION, J.F. \& ANDRIOLI, I. Qualidade física de um Latossolo Vermelho acriférrico sob diferentes sistemas de uso e manejo. R. Bras. Ci. Solo, 33:677-687, 2009.

ARAÚJO, M.A.; TORMENA, C.A. \& SILVA, A.P. Propriedades físicas de um Latossolo Vermelho distrófico cultivado e sob mata nativa. R. Bras. Ci. Solo, 28:337-345, 2004.

ASSIS, R.L. \& LANÇAS, K.P. Agregação de um Nitossolo Vermelho distroférrico sob sistemas de plantio direto, preparo convencional e mata nativa. Eng. Agríc., 30:58$66,2010$.

BANZATTO, D.A. \& KRONKA, S.N. Experimentação agrícola. 2.ed. Jaboticabal, FUNEP, 1992. 247p.

BAVER, L.D.; GARDNER, W.H.; GARDNER, W.R. Soil physics. 4.ed. New York, John Wiley \& Sons, 1972. 529p.

BEAR, J. Hydraulics of groundwater. New York, Mc GrawHill, 1979. 569 p.

BETIOLI JR, E.; MOREIRA, W.H.; TORMENA, C.A.; FERREIRA, C.B.; SILVA, A.P. \& GIAROLA, N.F.B. Intervalo hídrico ótimo e grau de compactação de um Latossolo Vermelho após 30 anos sob plantio direto. R. Bras. Ci. Solo, 36:971-982, 2012.

BEUTLER, A.N.; CENTURION, J.F.; SOUZA, Z.M.; ANDRIOLI, I. \& ROQUE, C.G. Retenção de água em dois tipos de Latossolos sob diferentes tipos de uso. R. Bras. Ci. Solo, 26:829-834, 2002.

BLAINSKI, E.; GONÇALVES, A.C.A.; TORMENA, C.A.; FOLEGATTI, M.V. \& GUIMARÃES, R.M.L. Intervalo hídrico ótimo num Nitossolo Vermelho distroférrico irrigado. R. Bras. Ci. Solo, 33:273-281, 2009. 
BLAKE, G.R. \& HARTGE, K.H. Particle density. In: KLUTE, A, ed. Methods of soil analysis: Physical and mineralogical methods. 2.ed. Madison, American Society of Agronomy, 1986. p.377-382.

CARPENEDO, V. \& MIELNICZUK, J. Estado de agregação e qualidade de agregados de Latossolos Roxos, submetidos a diferentes sistemas de manejo. R. Bras. Ci. Solo, 14:99$105,1990$.

CÁSSARO, F.A.M.; BORKOWSKI, A.K.; PIRES, F.L.; ROSA, A. \& SAAB, S.C. Characterization of a Brazilian clayey soil submitted to conventional and no-management practices using pore size distribution analysis. Soil Till. Res., 111:175-179, 2011.

CASTRO, O.M.; VIEIRA, S.R.; SIQUEIRA, G.M. \& ANDRADE, C.A. Atributos físicos e químicos de um Latossolo Vermelho eutroférrico sob diferentes sistemas de preparo. Bragantia, 68:1047-1057, 2009.

CAVALIERI, K.M.V.; SILVA, A.P.; TORMENA, C.A.; LEÃO, T.P.; DEXTER, A.R. \& HAKANSSON, I. Long-term effects of no-tillage on dynamics soil physical properties in a Rhodic Ferrasol in Paraná, Brazil. Soil Till. Res., 103:158-164, 2009.

CIOTTA, M.N.; BAYER, C.; ERNANI, P.R.; FONTOURA, S.M.V.; ALBUQUERQUE, J.A. \& WOBETO, C. Acidificação de um Latossolo sob plantio direto. R. Bras. Ci. Solo, 26:1055-1064, 2002.

COSTA JR, C.; PÍCCOLO, M.C.; SIQUEIRA NETO, M.; CAMARGO, P.B.; CERRI, C.C. \& BERNOUX, M. Carbono em agregados do solo sob vegetação nativa, pastagem e sistemas agrícolas no bioma cerrado. R. Bras. Ci. Solo, 36:1311-1321, 2012.

COUTINHO, F.S.; LOSS, A.; PEREIRA, M.G.; RODRIGUES JÚNIOR, D.J. \& TORRES, J.L.R. Estabilidade de agregados e distribuição do carbono em Latossolo sob sistema plantio direto em Uberaba, Minas Gerais. Comunicata Sci., 2:100-105, 2010.

CUNHA, E.Q.; BALBINO, L.C.; STONE, L.F.; LEANDRO, W.M. \& OLIVEIRA, G.C. Influência de rotações de culturas nas propriedades físico-hídricas de um Latossolo Vermelho em plantio direto. Eng. Agríc., 27:665-674, 2007.

CUNHA, E.Q.; STONE, L.F.; FERREIRA, E.P.B.; DIDONET, A.D. \& MOREIRA, J.A.A. Atributos físicos, químicos e biológicos de solo sob produção orgânica impactados por sistemas de cultivo. R. Bras. Eng. Agríc. Amb., 16:56-63, 2012.

DANIELSON, R.E. \& SUTHERLAND, P.L. Porosity. In: KLUTE, A., ed. Methods of soil analysis. 2.ed. Madison, American Society of Agronomy, 1986. Part 1. p.443-461.

DEXTER, A.R. Soil physical quality: Part I. Theory. Effects of soil texture, density, and organic matter, effects on root growth. Geoderma, 120:201-214, 2004.

EMPRESA BRASILEIRA DE PESQUISA AGROPECUÁRIA . EMBRAPA. Centro Nacional de Pesquisas de Solos. Manual de métodos de análises de solo. 2.ed. Rio de Janeiro, Embrapa Solos, 2011. 230p. Available: <http:// www.cnps.embrapa.br/publicacoes/>. Accessed: Mar. 03, 2012.
EMPRESA BRESILEIRA DE PESQUISA AGROPECUÁRIA EMBRAPA. Sistema brasileiro de classificação de solos. Rio de Janeiro, Embrapa Solos, 2006. 306p.

FONTENELE, W.; SALVIANO, A.A.C. \& MOUSINHO, F.E.P. Atributos de um Latossolo Amarelo sob sistemas de manejo no cerrado piauiense. R. Ci. Agron., 40:194-202, 2009.

HICKMANN, C.; COSTA, L.M.; SCHAEFER, C.E.G.R. \& FERNANDES, R.B.A. Morfologia e estabilidade de agregados superficiais de um Argissolo VermelhoAmarelo sob diferentes manejos de longa duração e mata atlântica secundária. R. Bras. Ci. Solo, 35:2191-2198, 2011.

Jong van LIER, Q. Índice "S": Um indicador da qualidade física do solo? B. Inf. Soc. Bras. Ci. Solo, 1:24-27, 2012.

KEMPER. W.D. \& CHEPIL, W.S. Size distribution of aggregates. In: BLACK, C.A., ed. Methods of soil analysis. Madison, American Society of Agronomy, 1965. Part 1. p.499-510.

KLUTE, A. Water retention: Laboratory methods. In: KLUTE, A., ed. Methods of soil analysis. 2.ed. Madison, American Society of Agronomy, 1986. Part. 1. p.635662.

LOSS, A.; PEREIRA, M.G.; SCHULTZ, N.; ANJOS, L.H.C. \& SILVA, E.M.R. Atributos químicos e físicos de um Argissolo Vermelho-Amarelo em sistema integrado de produção agroecológica. Pesq. Agropec. Bras., 44:68-75, 2009.

PINHEIRO, A.; TEIXEIRA, L.P. \& KAUFMANN, V. Capacidade de infiltração de água em solos sob diferentes usos e práticas de manejo agrícola. R. Amb. Água, 4:188199, 2009.

RAIJ, B.van; ANDRADE, J.C.; CANTARELLA, H. \& QUAGGIO, J.A. Análise química para avaliação da fertilidade de solos tropicais. Campinas: Instituto Agronômico de Campinas, 2001. 285p.

REICHARDT, K. \& TIMM, L.C. Solo, planta e atmosfera: Conceitos, processos e aplicações. 2.ed. Barueri, Manole, 2012. 524p.

REICHERT, J.M.; SUZUKI, L.E.A.S. \& REINERT, D.J. Compactação do solo em sistemas agropecuários e florestais: Identificação, efeitos, limites críticos e mitigação. In: CERETTA, C.A.; SILVA, L.S. \& REICHERT, J.M., eds. Tópicos em ciência do solo. 5.ed. Viçosa, MG, Sociedade Brasileira de Ciência do Solo, 2007. p.49-134

SALTON, J.C.; MIELNICZUK, J.; BAYER, C.; BOENI, M.; CONCEIÇÃO, P.C.; FABRÍCIO, A.C.; MACEDO, M.C.M. \& BROCH, D.L. Agregação e estabilidade de agregados do solo em sistemas agropecuários em Mato Grosso do Sul. R. Bras. Ci. Solo, 32:11-21, 2008.

SILVA, C.G.; ALVES SOBRINHO, T.; VITORINO, A.C.T. \& CARVALHO, D.F. Atributos físicos, químicos e erosão entressulcos sob chuva simulada, em sistemas de plantio direto e convencional. Eng. Agríc., 25:144-153, 2005. 
SILVA, V.L.; DIECKOW, J.; MELLEK, J.E.; MOLIN, R.; FAVARETTO, N.; PAUleTti, V. \& VEZZANI, F.M. Melhoria da estrutura de um Latossolo por sistemas de culturas em plantio direto nos Campos Gerais do Paraná. R. Bras. Ci. Solo, 36:983-992, 2012.

SILVA, F.F.; FREDDI, O.S.; CENTURION, J.F.; ARATANI, R.G.; ANDRIOLI, F.F. \& ANDRIOLI, I. Propriedades físicas de um Latossolo Vermelho cultivado no sistema plantio direto. Irriga, 13:191-204, 2008.

SILVA, S.G.C.; SILVA, A.P.; GIAROLA, N.F.B.; TORMENA, C.A. \& SÁ, J.C.M. Temporary effect of chiseling on the compaction of a Rhodic Hapludox under no-tillage . R. Bras. Ci. Solo, 36: 547-555, 2012.

SILVA, C.L. \& KATO, E. Efeitos do selamento superficial na condutividade hidráulica saturada da superfície de um solo sob cerrado. Pesq. Agropec. Bras., 32:213-220, 1997.

STONE, L.F.; GUIMARÃES, C.M. \& MOREIRA, J.A.A. Compactação do solo na cultura do feijoeiro I: Efeitos nas propriedades físico-hídricas do solo. R. Bras. Eng. Agríc. Amb., 6:207-212, 2002.

STRECK, C.A.; REINERT, D.J.; REICHERT, J.M. \& HORN, R. Relações do parâmetro S para algumas propriedades físicas de solos do sul do Brasil. R. Bras. Ci. Solo, 32:2603-2612, 2008.
TAVARES FILHO, J.; GUIMARÃES, M.F.; CURMI, P. \& TESSIER, D. Physical properties of an Alfisol and no-till soybean yield. R. Bras. Ci. Solo, 36:253-260, 2012.

TAVARES FILHO, J.; FONSECA, I.C.B.; RIBON, A.A. \& BARBOSA, G.M.C. Efeito da escarificação na condutividade hidraúlica saturada de um Latossolo Vermelho sob plantio direto. Ci. Rural, 36:996-999, 2006.

TORMENA, C.A.; SILVA, A.P.; IMHOFF, S.C. \& DEXTER, A.R. Quantification of the soil physical quality of a tropical Oxisol using the S index. Sci. Agric., 65:56-60, 2008.

van GENUCHTEN, M.T.A. A closed-form equation for predicting the hydraulic conductivity of unsaturated soils. Soil Sci. Soc. Am. J., 44:892-897, 1980.

VOLK, L.B.; COGO, N.P. \& STRECK, E.V. Erosão hídrica influenciadas por condições físicas de superfície e subsuperfície do solo resultantes do seu manejo, na ausência de cobertura vegetal. R. Bras. Ci. Solo, 28:763$774,2004$.

YODER, R.E. A direct method of aggregate analysis of soils and a study of the physical nature of erosion losses. J. Am. Soc. Agric., 28:337-351, 1936. 